\title{
Hip Synovitis in Dengue - Diagnostic Dilemma
}

\author{
Balachandar $\mathbf{G}^{1}$, Reddy $M N^{1}$, Rathinasamy $\mathbf{M}^{2}$ \\ From the Departments of Orthopaedics ${ }^{1}$ and Paediatrics ${ }^{2}$, Chettinad Hospital and \\ Research Institute, Kelambakkam, Kanchipuram District, Tamilnadu - 603103 , India.
}

\section{Abstract:}

Acute onset non-traumatic hip joint pain in children with fever is usually due to septic arthritis or transient synovitis. The association between dengue fever and isolated hip joint inflammation is not known. We present a case of a two-and-a-half year old girl with one week history of right hip pain, fever and inability to walk. She had painful range of hip motion and antalgic gait. Laboratory values were unremarkable, radiographs showed medial joint space widening and ultrasound revealed effusion. She was managed as transient synovitis of hip. During the course of stay, serology was positive for dengue fever. The child was treated symptomatically and recovered in ten days. In endemic zones, awareness of such presentation should be kept in mind to differentiate from benign condition like transient synovitis.

Key words: Dengue, Synovitis, Traction, Gait, Hip Joint, Child.

\section{Introduction}

Limping in a child under the age of three years with non-traumatic acute hip pain and fever is due to infection and/or inflammation of the joint [1]. A diagnosis of septic arthritis or transient synovitis befits most clinical scenarios [2]. Dengue infection causes fever, rash, retro-orbital headache, myalgia and arthralgia. However, arthritis is rare [3]. Atypical presentations are the forte of many infectious diseases. We present one case of acute dengue illness associated with unilateral hip joint synovitis, which confounded our working diagnosis of transient synovitis.

\section{Case Report}

A two-and-a-half year old girl from Chennai, Tamilnadu, India presented with a one week history of fever, painful right hip and limp. She was irritable with temperature of $100^{\circ} \mathrm{F}$, tachycardic $(122$ beats per minute), tachypneic (30 breaths $/ \mathrm{min}$ ) with normal blood pressure. Systemic examination was normal. The right hip was in $20^{\circ}$ flexion and $30^{\circ}$ external rotation. There was fullness of Scarpa's triangle of right hip compared to the left. It was tender with painfully restricted motion. She had an antalgic gait. Neurovascular status was normal. The left hip and other joints were normal. The relevant

Corresponding Author: Dr. Balachandar Gopalan

Email: drbala8782@gmail.com

Received: January 4,2014 | Accepted: January 25, 2014 | Published Online: February 5, 2014

This is an Open Access article distributed under the terms of the Creative Commons Attribution License (creativecommons.org/licenses/by/3.0)

Conflict of interest: None declared | Source of funding: Nil | DOl: http://dx.doi.org/10.17659/01.2014.0013 
laboratory workup is shown in Table 1.

Hip radiographs revealed increased right hip medial joint space [Fig.1] and ultrasonogram showed minimal effusion. Hence, she was treated as transient synovitis of hip and managed with skin traction, intravenous fluids and analgesics. She had febrile spikes (one spike per day, maximum recorded temperature $-100^{\circ} \mathrm{F}$ ) until sixth day, but her hip range of motion had improved on daily clinical examination. Interestingly, on the same day of her admission, her younger sister, 9 months old, with normal developmental and immunization history, was admitted with high grade fever and cough for a week. Clinically, she was febrile and liver was palpable $2 \mathrm{~cm}$ below costal margin. Her laboratory values showed lymphocytosis (differential lymphocyte count - 79.7) and low normal platelet values ( 1.6 lakhs $/ \mathrm{mm}^{3}$ ). She did

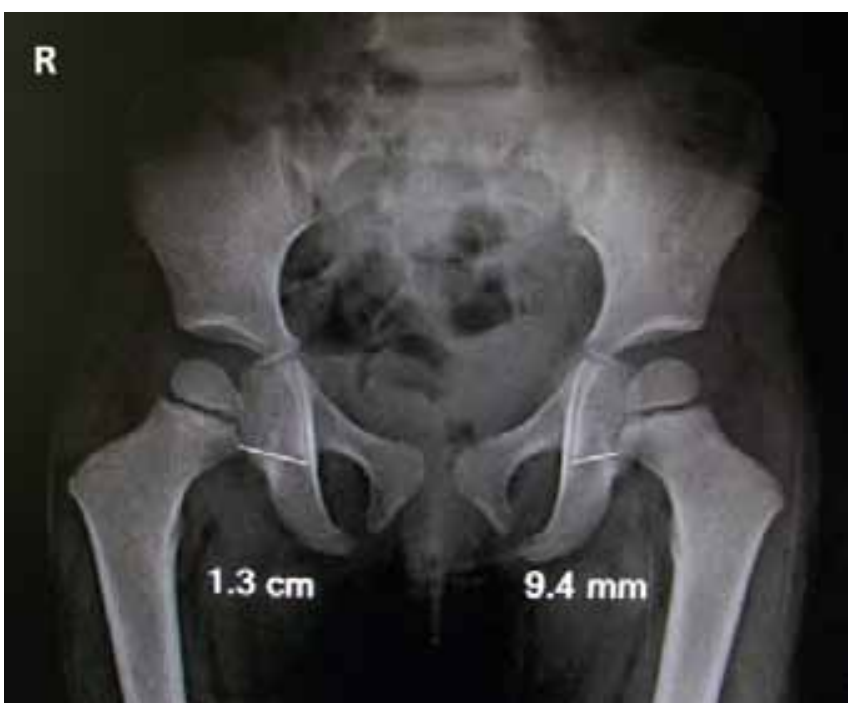

Fig.1: The right hip medial joint space is widened as compared to left hip. The periarticular fat pads are not displaced, which rules out septic arthritis.

Table 1: Laboratory Workup.

\begin{tabular}{|l|l|}
\hline Investigations & Report \\
\hline Hemoglobin & $10.4 \mathrm{~g} / \mathrm{dL}$ \\
\hline Total leucocyte count & $7,300 \mathrm{cells} / \mathrm{mm}^{3}$ \\
\hline Differential leucocyte count & $\mathrm{N}_{42} \mathrm{~L}_{47} \mathrm{E}_{1} \mathrm{~B}_{1} \mathrm{M}_{9}$ \\
\hline Platelet count & $3.43 \mathrm{lakhs} / \mathrm{mm}^{3}$ \\
\hline Erythrocyte sedimentation rate (ESR) & $31 \mathrm{~mm}$ in first hour \\
\hline Urea & $13 \mathrm{mg} / \mathrm{dL}$ \\
\hline Creatinine & $0.31 \mathrm{mg} / \mathrm{dL}$ \\
\hline Blood culture & Sterile \\
\hline Urine culture & Sterile \\
\hline Peripheral smear for malarial parasites & Negative \\
\hline Dengue Serology - IgM (Immunochromatography via SD card) & Positive \\
\hline Dengue Serology - IgG (Immunochromatography via SD card) & Negative \\
\hline
\end{tabular}


not have joint involvement. The similar patterns of fever occurring simultaneously prompted us to perform serological tests for dengue infection, and the results were positive for both siblings (positive $\lg M$, negative $\lg G)$.

With supportive therapy, both the children recovered uneventfully. Repeat ultrasonogram of right hip in the older sibling on ninth day revealed no effusion. She began walking normally on tenth day and was discharged. She was reviewed two weeks later and ultrasonogram revealed no effusion. At follow-up visit after four months, the child was healthy with symmetrical hip joint spaces [Fig.2].

\section{Discussion}

Transient synovitis, septic arthritis, osteomyelitis of upper femur, pauciarticular juvenile arthritis, and leukemia are differential diagnoses in a toddler with febrile arthritis $[1,4,5]$. Post-infectious arthritis follows infection by organisms (Chlamydia, Salmonella) from genitourinary tract, gastrointestinal tract or respiratory tract [6]. In endemic areas, malaria, dengue and chikungunya are known to cause febrile arthritis [7].

Transient synovitis is a benign self-limiting condition which involves children between 3-8 years, with a slight male preponderance, acute onset hip pain with inability to bear weight, occasionally low grade fever, antecedent viral illness, absence of specific laboratory markers and spontaneous resolution in 3-10 days [8]. Septic arthritis is diagnosed with $99.6 \%$ probability based on presence of all of Kocher criteria (fever over $101.3^{\circ} \mathrm{F}$, inability to tolerate body weight, ESR $>40 \mathrm{~mm} / \mathrm{hr}$, total leucocytes $>12,000$ cells $/ \mathrm{mm}^{3}$ ) $[9,10]$. Based on her clinical and investigative profile, osteomyelitis, juvenile arthritis and leukemia were excluded. Septic arthritis was ruled out by fever $<101.3^{\circ} \mathrm{F}$, total leucocyte count of $7300 / \mathrm{mm}^{3}$ and ESR of $31 \mathrm{~mm}$ in first hour (probability of septic arthritis in presence

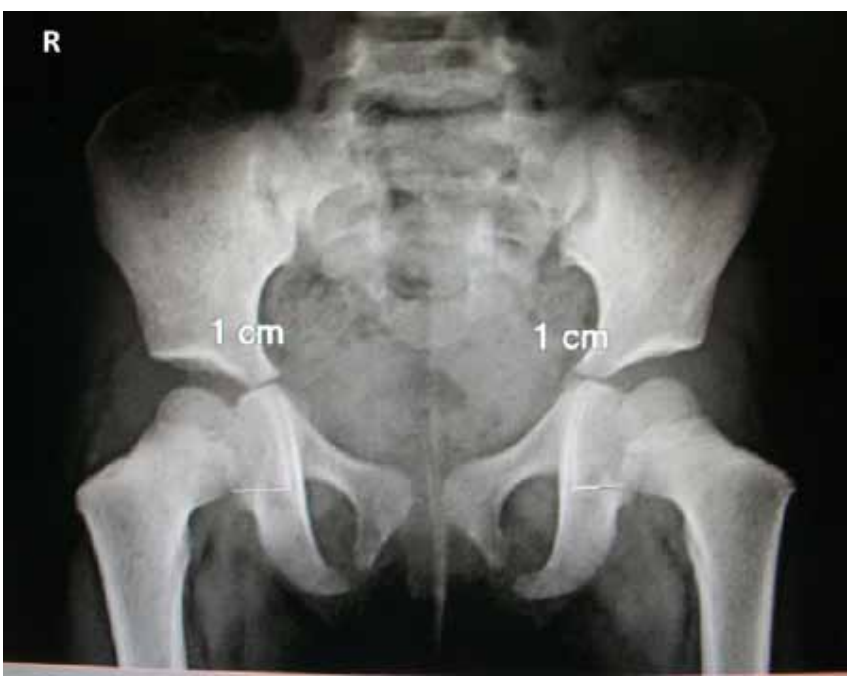

Fig.2: At 4 months follow-up, bilateral hip joint spaces are equal.

of one criteria is $3 \%$ ). Moreover, the radiographic evidence of preserved periarticular fat pads and the day-by-day clinical improvement dissuaded us from performing advanced imaging such as MRI of the hip (which was expensive and not feasible owing to the indolent course of disease) and joint aspiration (which was invasive and unnecessary in the light of low pretest probability).

Dengue, an endemic disease in Chennai which is caused by an arthropod-borne flavivirus, is characterized by fever with rash, myalgia, arthralgia, conjunctival congestion and headache $[11,12]$. In children, it follows a bimodal pattern with primary cases at seven months of age and secondary infections at three to five years of age [11]. The diagnosis is based on clinical features and serological tests, namely $\lg M, \lg G$ and NS- 1 (non-structural protein-1) detection [13,14]. IgM is detected after five or more days of onset of illness. Ig $G$ indicates secondary infection. Hence, in this case, $\lg M$ positive and $\lg G$ negative indicates primary dengue infection [13]. The NS-1 marker is highly specific, positive upto nine days after illness, and it is useful when the viral load is high, 
i.e, if the test is done on the first day of fever or in uncomplicated cases [14]. As the child presented to us after seven days of fever and had no complications, we did not perform the NS-1 assay. The platelet counts were normal in this patient, which is seen in 18-19\% of cases $[11,15]$. Chikungunya, an important differential diagnosis for dengue, is characterized by fever, arthralgia involving small joints for prolonged duration and rash caused by alpha virus, associated with lymphopenia, anemia and elevated serum creatinine levels [16]. Absence of polyarthralgia, rash and presence of relative lymphocytosis made Chikungunya a less likely diagnosis.

The diagnostic dilemma in this case was to determine whether the hip problem was due to dengue infection or transient synovitis. The presence of fever, arthralgia, seropositivity for $\lg M$, selflimiting nature in two weeks, and simultaneous dengue infection in the siblings hailing from same endemic zone favoured our diagnosis of dengue infection. Our patient was initially managed as transient synovitis of hip, which is a diagnosis of exclusion. Jung et al, in their study of 97 cases of transient synovitis showed that probability of

Table 2: Clinically relevant parameters in transient synovitis, septic arthritis and the present case.

\begin{tabular}{|c|c|c|c|}
\hline $\begin{array}{c}\text { Clinical and Laboratory } \\
\text { profile }\end{array}$ & Transient synovitis & Septic arthritis & Our Case \\
\hline General condition & Normal & Irritable, malaise & $\begin{array}{c}\text { Irritable, tachycardic, } \\
\text { tachypneic }\end{array}$ \\
\hline Clinical examination & $\begin{array}{l}\text { Painful passive motion } \\
\text { range of right hip } \\
\text { motion }\end{array}$ & $\begin{array}{l}\text { Painful range of right } \\
\text { hip motion, local } \\
\text { warmth, erythema, } \\
\text { tender joint }\end{array}$ & $\begin{array}{c}\text { Painful range of right } \\
\text { hip motion }\end{array}$ \\
\hline Maximum Temperature & Rarely $>38^{\circ} \mathrm{C}$ & $>38^{\circ} \mathrm{C}$, chills, rigor & $37.7^{\circ} \mathrm{C}$ \\
\hline WBC count (cells $/ \mathrm{mm}^{3}$ ) & $<12000$ & $>12000$ & 7300 \\
\hline $\mathrm{ESR}(\mathrm{mm} / \mathrm{hr})$ & $<40$ & $>40$ & 31 \\
\hline Dengue Serology & Negative & Negative & $\lg M+, \lg G-$ \\
\hline $\begin{array}{l}\text { Radiographic joint space } \\
\text { difference }(\mathrm{mm})\end{array}$ & $\begin{array}{l}<2, \text { preserved } \\
\text { periarticular fat pads }\end{array}$ & $\begin{array}{l}>2 \text {, displaced } \\
\text { periarticular fat pads }\end{array}$ & $\begin{array}{c}\text { 3.6, preserved } \\
\text { periarticular fat pads }\end{array}$ \\
\hline Ultrasonogram & $\begin{array}{l}\text { Mild-moderate } \\
\text { effusion }\end{array}$ & Severe effusion & Mild effusion \\
\hline Treatment & $\begin{array}{l}\text { Bed rest, traction, } \\
\text { analgesics }\end{array}$ & $\begin{array}{c}\text { Arthrotomy and } \\
\text { drainage, antibiotics }\end{array}$ & $\begin{array}{l}\text { Bed rest, traction, } \\
\text { analgesics }\end{array}$ \\
\hline $\begin{array}{l}\text { Sequelae (if left } \\
\text { untreated) }\end{array}$ & $\begin{array}{l}\text { Self limiting in 3-10 } \\
\text { days, with no serious } \\
\text { sequelae }\end{array}$ & $\begin{array}{l}\text { Destruction of } \\
\text { articular/ physeal } \\
\text { cartilage, dislocation } \\
\text { of hip, ankylosis }\end{array}$ & $\begin{array}{c}\text { Dengue hemorrhagic } \\
\text { fever/ dengue shock } \\
\text { syndrome ( } 5-10 \% \\
\text { cases) }\end{array}$ \\
\hline
\end{tabular}


transient synovitis was low when fever exceeded $37^{\circ} \mathrm{C}\left(98.6^{\circ} \mathrm{F}\right), \mathrm{ESR}>20 \mathrm{~mm} / \mathrm{hr}$ and difference of hip joint space distance $>2 \mathrm{~mm}$, as evident in this case [17]. A careful scrutiny of the important clinical, hematological and radiological features, shown in Table 2, demonstrates that this child had features unlike that seen in transient synovitis or septic arthritis.

Dengue virus infection ranges from asymptomatic infection to dengue fever. $5-10 \%$ cases progress to Dengue Hemorrhagic Fever (DHF) and Dengue Shock Syndrome (DSS), which can result in death if not managed properly [13]. Atypical dengue presentations such as encephalitis and myositis have been mentioned [11]. Patil and Akki [18] described a case of postviral arthritis of knee joint due to dengue in a 28 month old child. Pyomyositis of obturator internus and gluteus maximus can confound a case of transient synovitis or septic arthritis $[19,20]$. But, dengue-related unilateral hip synovitis masquerading as transient synovitis of hip has not been reported in literature. Moreover, children are at a higher risk of DHF than adults due to higher baseline microvascular permeability [11].

\section{Conclusion}

This case is an unusual presentation of dengue infection and differentiation from benign condition such as transient synovitis is mandatory. Dengue is a potentially dangerous disease wherein children are more susceptible to its severe clinical forms. Atypical presentation of dengue infection should be considered when treating children with fever and hip pain in endemic zone.

\section{References}

1. Herring JA. The Limping Child. In: Tachdjian's Pediatric Orthopaedics, $4^{\text {th }}$ ed. Saunders Elsevier: Philedephia; 2008.pp.89-104.

2. Liberman B, Herman A, Schindler A, Sherr-Lurie
N, Ganel A, Givon U. The value of hip aspiration in pediatric transient synovitis. J Pediatr Orthop 2013;33:124-127.

3. Adebajo AO. Dengue arthritis. Br J Rheumatol. 1996;35:909-910.

4. Griffin PP. Bone and joint infections in children. In: Chapman MW (ed). Chapman's Orthopaedic Surgery, $3^{\text {rd }}$ Ed. Lippincott Williams \& Wilkins; 2001.pp.4470-4474.

5. Tuten HR, Gabos PG, Kumar SJ, Harter GD. The limping child: A manifestation of acute leukemia. J Pediatr Orthop 1998; 18:625-629.

6. Gupta N, Singh N, Malik S. Bilateral Peroneal Axonal Neuropathy: A Rare Post-malarial Neurological Syndrome. Journal of Case Reports. 2013;3(2):433-435.

7. Franssila R, Hedman K. Viral causes of arthritis. Best Pract Res Clin Rheumatol 2006;20:1 1391157.

8. Nouri A, Walmsley D, Pruszczynski B, Synder M. Transient synovitis of the hip: a comprehensive review. J Pediar Orthop B. 2014;23(1):32-36

9. Espinoza LR, García-Valladares I. Microbios y articulaciones: la relación entre infección y articulaciones. Reumatol Clin 2013;9:229-238.

10. Kocher MS, Zurakowski D, Kasser JR. Differentiating between septic arthritis and transient synovitis of the hip in children: An evidence-based clinical prediction algorithm. J Bone Joint Surg [Am] 1999;81:1662-1670.

11. Banerjee M, Chatterjee T, Choudhary GS, Srinivas $V$, Kataria VK. Dengue: A clinicohaematological profile. Medical Journal Armed ForcesIndia 2008;64:333-6.

12. Arunachalam N, Tewari SC, Thenmozhi V, Rajendran R, Paramasivan R, Manavalan, R, et al. Natural vertical transmission of dengue viruses by Aedes aegypti in Chennai, Tamil Nadu, India. Indian J Med Res. 2008; 1 27:395-397.

13. Peeling RW, Artsob $H$, Pelegrino JL, Buchy P, Cardosa MJ, Devi $S$, et al. Evaluation of diagnostic tests: Dengue. Nat Rev Microbiol. 2010;8:S30-38. 
14. Kulkarni RD, Patil SS, Ajantha GS, Upadhya AK, Kalabhavi AS, Shubhada RM, et al. Association of platelet count and serological markers of dengue infection - importance of NS1 antigen. Indian J Med Microbiol. 2011 ;29:359-362.

15. Ratagiri H, Shepur TA, Wari PK,Chavan SC. Clinical profile and outcome of Dengue fever cases. Ind J Paediatrics. 2005;72:705-706.

16. Thiberville SD, Moyen N, Dupuis-Maguiraga L, et al. Chikungunya fever: Epidemiology, clinical syndrome, pathogenesis and therapy. Antiviral Res. 2013;99:345-370.

17. Jung ST, Rowe SM, Moon ES, Song EK, Yoon
TR, Seo HY. Significance of laboratory and radiologic findings for differentiating between septic arthritis and transient synovitis of the hip. J Pediatr Orthop 2003;23:368-372.

18. Patil MM, Akki AS. Dengue arthritis in a child. Indian Pediatr. 2013;50:522-523.

19. Chung JW, Bagali M, Kaneker S. Physical signs in pyomyositis presenting as a painful hip inchildren: a case report and review of the literature. J Pediatr Orthop B. 2004; 13:211-213.

20. Bansal M, Bhaliak V, Bruce CE. Obturator internus muscle abscess in a child: a case report. J Pediatr Orthop B. 2008; 17:223-224. 